Piera Molinelli. 2018. Sociocultural and linguistic constraints in address choice from Latin to Italian. In Beeching, Kate, Ghezzi, Chiara \& Molinelli, Piera (eds.), Positioning the self and others. Linguistic Perspectives. 51-79. Amsterdam: Benjamins (Pragmatics \& Beyond New Series 292) https://doi.org/10.1075/pbns.292.03mol

This is the 'author accepted manuscript'. It is under copyright and the publisher should be contacted for permission to re-use or reprint the material in any form.

(cf. https://www.benjamins.com/content/authors/rightspolicy)

\title{
Chapter 3: Sociocultural and linguistic constraints in address choice from Latin to Italian
}

Piera Molinelli

\begin{abstract}
This chapter identifies the changes which led from the Early Latin address system, when address choice was unmarked as to the reverential dimension, to Late Latin, when such functions progressively emerged establishing the opposition between $t u$ and $\operatorname{Vos}(2 \mathrm{PL})$, and then to the Italian system. Speakers of Old Italian continued the differentiation in the address system, and, starting from the $t u / V o s$ opposition, subsequent developments led to a tripartite system $(t u /$ Voi/Lei $)$.

The chapter traces the main pragmatic and structural steps in the development of address terms and the external and internal factors involved. Whereas the emergence of reverential forms in the history of Latin is mainly due to socio-cultural factors, the change from Voi to Lei can be attributed to both social (contact with Spanish) and linguistic factors, since the use of honorifics triggered anaphoric abstract reference to a third person, then morphologised as third singular pronouns (Lei).
\end{abstract}

Key words: Politeness, address system, Latin, Italian, honorifics, tu/Vos pronouns. 


\section{Introduction}

This paper investigates the linguistic and sociocultural factors, which triggered and constrained changes in address choice from Latin to Italian, thus adopting a socio-historical pragmatic perspective familiar from a well-established body of research (see, e.g., Culpeper and Kytö 2000, Taavitsainen and Jucker 2003, Andersen and Aijmer 2011, Ghezzi 2015). In particular, this study explores how speakers recruited different pronouns in interaction, among the choices available to them, at various moments throughout the long chronological period taken into account. The main aim in this respect is to apply a diachronic perspective to the reconstruction of interactional patterns crucial to speakers' social positioning.

The Italian system of pronouns owes to Latin the distinction between a system based on a single pronoun of address and one based on two pronominal forms, where one is marked as deferent. Classical Latin had an address system with a single pronoun of address ( $t u, 2 \mathrm{SG}$ ), while Late Latin shows the first attestation of a system characterized by a two-term situation ( $t u-V o s, 2 \mathrm{PL})^{1}$. Speakers of Old Italian continued the differentiation between an unmarked pronoun of address $t u$ and a deferent pronoun Voi. From the fifteenth century on, the system of pronouns of address can be schematized as a three-term situation where two deferent forms are attested, as Voi coexists with Lei (3SG.F). In the twentieth century, deferent Voi was progressively abandoned in the standard language in favour of Lei, which characterizes the standard Italian system of address today. However, in a number of Southern and Central varieties of Italian, Voi remains the unmarked deferent pronominal form. Throughout their histories, the Latin and Italian systems of address also included nominal forms, which have played a role in the development of their respective pronominal systems.

Let us now briefly characterize the pragmatic import of address forms. Speakers select the pronoun of address and related forms in interaction on the basis of parameters of social and affective distance (see Molinelli 2015a). Social distance implies some kind of asymmetrical, non-reciprocal relationship

\footnotetext{
${ }^{1}$ The capital letter in Vos and the following, Voi and Lei with the clitic forms Vi/Ve and Le are conventionally used to signal the deferent form.
} 
(based for instance on age, or role in society). In such contexts, the interlocutors have different, asymmetrical degrees of power in the interaction. Non-reciprocal power semantics only prescribes usage between superior and inferior and calls for social structures in which there are unique power rankings for each individual. Affective distance is characteristic of symmetrical and reciprocal relations, differentiating address among power equals, expressing degree of intimacy rather than respect or formality.

Systems of address are pragmatic in essence because they serve to position the interlocutors' identity and depend on the system of social rules that governs their behaviour in a given historical context ${ }^{2}$. On the one hand, the system of address is central to communication as it defines, shapes and indexes both the speaker's and the interlocutor's identity and their mutual social relationship. It is independent of the content which is being conveyed in an interaction and is made up of both verbal and non-verbal elements, constituting a system in Saussure's terms: what constitutes the social deixis system which is anchored to a given socio-cultural context are not single elements, but their coherent integration.

On the other hand, address systems in Latin and Italian - and more generally in Indo-European languages - comprise nominal forms (titles, honorifics) and pronominal forms, and possibly, verbal agreement. Both nominal and pronominal forms rely on the speaker's choice, while verbal agreement is due to the grammatical constraints of the language. Together, these means enable speakers to distinguish familiar and affective values from reverential and polite ones. These values are deeply rooted in the socio-cultural situation and can change rapidly according to political, social, and cultural transformations, whenever previously established criteria are substituted or enriched by newer ones, which give rise to a new system.

\footnotetext{
2 Relevant research studies on the relationship between personal pronouns and pragmatic values include: Head 1978 (especially for typological considerations), Malsch 1987 and Helmbrecht 2003 on the relationship between politeness and personal pronouns, and Helmbrecht 2015 as regards the concept of "non proto-typical uses of personal pronouns". Nevertheless, some of Helmbrecht's statements about the areal and typological trends, which affect politeness motivated pronouns, sound less respectful of the peculiar diachrony of each of the languages considered. In particular, his idea that the development of the second person plural as an honorific pronoun was an areal feature of European languages which occurred from medieval times onwards (2015: 186) does not take the role of Latin sufficiently into account. On the whole, his studies demonstrate how necessary it is to combine a typological approach with diachronic studies.
} 
Both the properties of the system of address just described above are probably two of the reasons why the system lies at the periphery of grammar, and its forms and functions are subject to rapid and dramatic changes in diachrony.

The aim of this contribution is twofold. First, it aims to discuss which nominal and pronominal forms have been selected by individual speakers or groups of speakers in order to position themselves socially and culturally through the centuries. We will see that, by means of their interactionally-based choices, Latin and Italian speakers have progressively reshaped the constellation of the available address forms in extra-linguistic circumstances which dynamically evolved over time. The paper therefore also aims to analyse the main socio-cultural factors at play and the norms for language usage, which enabled speakers to represent their identities through different forms of address at different moments, but also that prompted and favoured a change in the system itself in the long run, from Latin to Present-Day Italian. In what follows, we will therefore highlight some relevant synchronic steps, which turned out to be crucial in the pragmatic development under scrutiny: Classical Latin, Late Latin, Old Italian, and subsequent changes in 16th/20th century Italian.

Due to the diachronic nature of the present study, this chapter has a slightly different organization from the other chapters in the volume. The article is divided into different sections, which synthesize remarks outlined in relevant literature with new findings from analysis of empirical data.

The structure of the paper is as follows. In Section 2, data and methods are presented, with a focus on their qualitative properties. In Section 3, the evolution of the system of address through the centuries is outlined, moving from Classical and Late Latin, where sociocultural customs triggered the emergence of new pragmatic strategies, namely pluralization and honorifics. In Section 4 , the development of the system of address is taken into account in Old Italian, and then in 16th-century, 18th-century, and $20^{\text {th }}$-century Italian, respectively. In Section 5, the main results of the analysis are summarized.

\section{Data and methods}


A sociopragmatic approach to written texts of the past requires methodological caution. On the one hand, the texts at our disposal provide evidence of textual choices which only indirectly mirror the actual choices made by speakers (or better, by writers). This means that this study cannot properly be considered as accounting for the speakers' choices at specific synchronic moments. Rather, the texts considered show the possibilities that speakers had when using forms belonging to the address system current at the time, in different written genres (e.g., epistolary exchanges and mimetic dialogues contained in comedies) and at different moments, along an extended diachrony of two distinct languages.

On the other hand, our corpus of written documents allows us to explore the nature of the Latin and Italian systems of address, and the changes which occurred, since the selection of the corpus has been inspired by what Culpeper and Kytö (2000: 177-178) call "constructed imaginary speech", characterized by "features which can be assumed to be strongly associated with spoken face-to-face interaction". ${ }^{3}$ Therefore, the texts on which this analysis is based all mirror, in some way, mimetic patterns of actual language use, in accordance with norms and practices of the periods in question. In order to describe the complex diachronic development at issue, this chapter takes a qualitative approach to different types of textual genres representative of the imaginary speech, each differentiated on a historical basis ${ }^{4}$.

For Latin, we offer a qualitative account of the main developments which occurred in the ways people addressed each other between Classical and Late Latin (90 BCE - 600 CE ca.) and which are illustrated through selected examples drawn from texts which are representative of the historical periods under investigation (e.g., Cicero and Caesar for Classical Latin). We have considered such different textual genres as private letters, orations, and imperial rescripts ${ }^{5}-$ genres where speakers'

\footnotetext{
${ }^{3}$ Culpeper and Kyto (2000) look at speech-related written text types, distinguishing between recordings of speech (e.g., trial proceedings) and constructions of speech (e.g. drama, speech representation in prose fiction, and educational handbooks in dialogue form).

${ }^{4}$ Some data in the chapter refer to previous quantitative studies, quoted at appropriate points.

${ }^{5}$ A rescript, following the Collins dictionary, is "(in ancient Rome) an ordinance taking the form of a reply by the emperor to a question on a point of law".
} 
positioning was particularly relevant, thus revealing address patterns, which presumably mirror contemporary linguistic conventions ${ }^{6}$.

For Italian we consider letters, which represent a direct written interaction, where sociopragmatic matters are of the highest relevance, and comedies, which contain interactions between speakers of different social classes, thus illustrating the sociolinguistic dynamics of the time.

\section{The development of the system of address in Latin}

\subsection{Classical Latin}

In Classical Latin, ${ }^{7}$ the system of address is built upon two main strategies ${ }^{8}$.

Nominal forms represent the main strategy, and proper names are the most frequent: the use of praenomen, nomen and cognomen could modulate and express different address types (Dickey, 2002: 56-67). Other frequent strategies included titles (dominus 'master'), kinship terms, terms to express affect and esteem (carissima 'very darling': Dickey, 2002: 136ff.), and figuratively used terms like cor 'heart' (Dickey, 2002: 152).

The second strategy implies the use of pronouns. $T u$ is the only option available, as Classical Latin does not feature reverential pronouns ${ }^{9}$. Evidence for the exclusive use of $t u$ comes from early comedies and letters, and from the greeting formulae used by gladiators to address the emperor, which survived even after the Classical period:

(1) Svet. Claud. 21, 6 Have, Imperator, morituri te salutant

'Hail, Emperor, those who are about to die salute you'

\footnotetext{
${ }^{6}$ For Latin, we do not have comedies in the late period; Plautus' comedies $\left(3^{\text {rd }}-2^{\text {nd }}\right.$ century B.C.) do not distinguish reverential forms of address though several politeness strategies can be recognized (Dickey 2002, Unceta Gomez 2017). ${ }^{7}$ We assume the periodization proposed by Cuzzolin and Haverling (2009: 20): Classical Latin 90 BCE - 14 CE; Postclassical Latin 14 - ca 200 CE; Late Latin 200 - 600 C.E.

${ }^{8}$ The system of address is a relevant part of politeness. Unceta Gomez (2014) and Ferri (2008) are basic readings on this issue in Latin.

${ }^{9}$ Even a frequently cited passage such as that found in Ennius (VIII 377), nos sumus Romani, qui fuimus ante Rudini 'now am I Roman who before was citizen of Rudiae' but literally 'now are we Roman who before were citizens of Rudiae', represents a controversial case: the plural here could have been used by the poet to recall his tria corda 'three hearts' i.e., Oscan, Latin and Greek languages.
} 
However, already in Classical Latin a new pluralization strategy emerges, which is based on the use of the plural pronoun nos instead of ego for the expression of sociative and inclusive values ${ }^{10}$. In this perspective, nos literally points to the inclusion of the addressee and evokes a sense of commonality and close relationship, also enhancing participation, interest and support (cf. Lilja 1971; Hofmann, 2003: 291; Brown and Levinson, 1987: 127). By including the interlocutor within an action that, in principle, does not require his intervention, the speaker wishes to establish a more direct contact, and the outcome of this supportive move is to trigger a close association ${ }^{11}$.

In Cicero's letters, the inclusive plural is widely attested as associating the interlocutor within a move of appraisal or contempt, in order to reinforce or mitigate a precise communicative move - and this can happen even if the letter is sent only to his friend Atticus:

(2) Cic. Att. IX, 6, 2 sed opinor quiescamus, ne nostram culpam coarguamus qui, dum urbem, id est patrias, amamus dumque rem conventuram putamus, ita nos gessimus ut plane interclusi captique simus.

'But I suppose I (=we) had better keep quiet, for fear of convicting myself of folly in managing to be cut off wholly and made captive through my love of my country and an idea that the matter could be patched up'

In orations, Cicero frequently uses the inclusive plural to associate his client with himself or to show his own participation and involvement in his cause (Ronconi, 1946: 2):

(3) Cic. P. Sex. R. Am. 52, 150 unum perfugium, iudices, una spes reliqua est Sex. Roscio...vestra pristina bonitas et misericordia. Quae si manet, salvi esse possumus

'the only refuge, the only hope that is left for Sextus Roscius is ... the kindheartedness and

\footnotetext{
${ }^{10}$ Head (1978: 164, n. 10) recalls some preceding works by Muller, Jespersen, Bean, Brunot and their observations about different meanings and definitions of the plural-for-singular first person pronoun. Head, in the same footnote, underlines the uniqueness of the status of the plural in the first person of self-reference: usually "it does not refer to several speakers... The difference between exclusive and inclusive uses of the plural in the first person perhaps underlie the alleged distinctions in meaning between "royal we", "editorial we" and the "plural of modesty. "Royal we" is normally exclusive, referring only to the speaker, while "editorial we" and the "plural of modesty" tend to be inclusive, associating the speaker with the addressee(s), the notional third person or both".

${ }^{11}$ This is particularly evident if one considers forensic rhetoric, which is characterized by communicative patterns that foster the development of this pragmatic function. Cf. Molinelli (2015b) for a detailed discussion of these uses in Cicero's Verrine.
} 
compassion which you showed in earlier times. If these feelings abide, we can even now be saved' (that is: 'Sex. R. can be safe')

Particular types of the inclusive plural which date back to Classical Latin are referred to as pluralis auctoris and pluralis modestiae, i.e., the use of nos for ego in speaking of oneself and one's own actions. In doing so, the speaker downplays his individual personality and identifies with his audience: thus, pluralization acquires a modesty value, since the author does not emphasize his own creative process, highlighting instead the affective relationship that he has established with his readers (Pieri, 1967: 217-218). By means of a plural reference, the personality of the author is defocalised and blurred in a plurality of subjects:

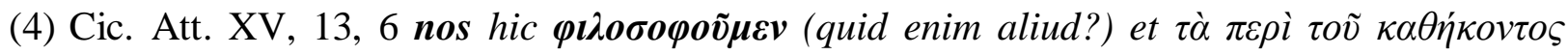
magnifice explicamus $\pi \rho \sigma \sigma \varphi \omega v o \tilde{\mu} \varepsilon \varepsilon q u e ~ C i c e r o n i$

'I am philosophizing here (what else can I do?) and getting on splendidly with my De Officiis, which I am dedicating to my son'

The vitality of this pragmatic strategy is witnessed by the fact that it continues to be used in later periods. A case in point is the First letter of Pope Clemens ${ }^{12}$. In (5) it is clear that Clemens is the only, single author; however, Clemens uses the plural to refer to his own act of writing and remembering to generalize the scope of his actions, thus conferring universal validity to his thoughts.

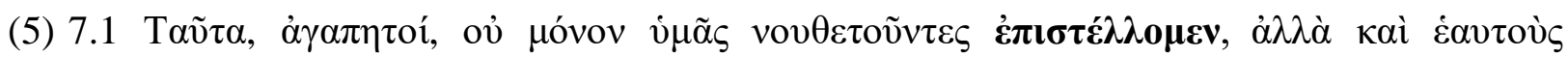

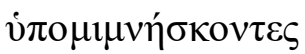

Haec, carissimi mihi, non solum vos monentes scribimus, sed et nos metipsos conmonemus.

'My very beloved, we write all these things not only to admonish you, but also to remember them to ourselves'

\footnotetext{
12 The passage in (5) (and all the following from the same document) shows the Greek and the Latin text of the First Letter of Pope Clemens, since the letter is originally written in Greek (presumably around the end of the first century C.E.), like all the Christian documents of the first two centuries.
} 
Summing up, in Classical and Post-Classical Latin (90 BCE - ca. 200 CE) the system of address is not distinctive of asymmetric relationships, at least considering the texts at our disposal; a pluralization strategy emerges in the first person with inclusive values (sociative, of modesty). It is worth mentioning the clear distinction proposed by Head (1978: 165 fn.10) between inclusive vs. exclusive uses of the first person plural: "Use of the first person plural to show greater respect or social distance is exclusive, while inclusive use indicates proximity between the speaker and the other referent(s)"13. In Latin diachrony, this distinction is chronologically recognisable with the inclusive use occurring first.

\subsection{Late Latin}

In Late Latin, some changes affected the system of address both in the nominal and in the pronominal domains.

The nominal strategy turned out to be very productive in Late Latin both in secular and in Christian contexts. Late texts reveal that there is an increasing tendency to address a person using abstract nouns accompanied by the possessive adjective, with honorific and reverential value. This reverential nominal strategy was already attested in Early Latin ${ }^{14}$, but it is at this chronological stage that it reaches a systematic codification within the system of social deixis. Fridh (1956: 169) highlights how abstracts nouns used as honorifics are typical of Greek and Latin letters, and reflect a tendency, common to rhetoric and poetic styles as well as to popular language, to personify an abstract quality. The semantic and pragmatic development of maiestas 'majesty' can serve as an interesting example here, since its functional enrichment mirrors the emergence of the reverential values just described. Originally, maiestas had a religious sense and was used to refer to the emperor, depicting him as a divinity (see Svennung, 1958: 71). In Classical Latin we find the first cases in which maiestas was used to refer to the princeps (ex. 6 and Ovid. trist. 2, 512). Later, in the first century CE, we have a

\footnotetext{
${ }^{13}$ In Heads' words, respect and social distance are not clearly distinct. These sociocultural concepts and their linguistic reflexes are central in several studies on politeness (Molinelli 2002, Renzi 1993).

${ }^{14}$ See e.g. Hofmann and Szantyr, 1965: 101-102 and the detailed lists provided by Dickey, 2002: 132-3, 152-153.
} 
passage attested in the Vindolanda tablets where maiestas refers to someone of lower status, presumably the provincial governor (ex. 7):

(6) Hor. ep. 2, 1, 258 sed neque parvum carmen maiestas recepit tua

'but neither does your majesty admit of a lowly strain'

(7) 344, 4.5 [..]mine probo tuam maies-

[t]atem imploro ne patiaris me

[i]nnocentem uirgis cas[t]igatum

esse

'As befits an honest man (?) I implore your majesty not to allow me, an innocent man, to have been beaten with rods'

It is important at this point to underline that the passages by Horace and Ovid constitute two bridging contexts $^{15}$ attributing the quality linked to maiestas to Augustus. Significantly, this use first appears in poetry texts and does not seem to reflect a stabilized pragmatic strategy of social deixis. Further evidence for this comes from the fact that in the examples given above the use of the second-person singular (tua) always appears, which demonstrates that the reverential value of the second plural has not yet come to light. Along the same lines, Fridh (1956: 170) argues that such titles "ne sont pas encore à regarder comme de vrais titres consacrés par l'usage et que l'origine de ces titulatures n'est probablement pas antérieure au début du IVe siècle" ('are not yet to be regarded as real titles enshrined in usage and that the origin of these titular forms doesnot arise before the beginning of the 4th. Century'.

In (7), an innocent man is imploring the "majesty" of the local governor: similar to (6), maiestas is not employed with an addressing value in a proper allocutive sense, but bears the constitutive trait of the person who is being implored. The attribution of this specific quality to a person constitutes the bridging context that determines a further complete identification of the interlocutor with the abstract

\footnotetext{
15 The definition 'bridging context' is due to Heine (2002) and seems now to be widespread among scholars, while Diewald (2002) uses 'critical'. Both indicate contexts in between from a syntactic and/or semantic point of view.
} 
quality expressed by maiestas. This process explains why in Late Latin the writer may refer directly to the interlocutor using the name that expresses the abstract positive quality that best represents him. Such instances exemplify important steps along the road to the conventionalization of maiestas, the intrinsic qualities of which were gradually pragmatically exploited as a means of social deixis. The increasing frequency of maiestas as a pragmatically stable honorific term of address is demonstrated by the wider use of it made by authors like Quintilian and Pliny; and between the $3^{\text {rd }}$ and the $4^{\text {th }}$ centuries, these nominal forms of address were systematically used as titles for emperors by the Scriptores historiae Augustae and by Symmachus.

Other expressions pragmaticalized in a similar vein: tua pietas 'your piety', for instance, is found as early as in Quintilian and Pliny (cf. Ep. 10, 1); later adoptions are claritas 'brightness', clementia 'clemency', excellentia 'excellence', magnificentia 'magnificence', magnitudo 'greatness', and, to refer to popes and bishops, also sanctitas tua 'your holiness'. Complementary to the use of positive address nominals, new expressions of modesty emerge: examples would be mediocritas nostra 'our modest self' (e.g., Vell. 2, 111, 3) and mea parvitas 'my littleness' (e.g., Val. Max. 1, praef.), which pragmaticalized to refer to oneself while interacting with the emperor from the age of Tiberius onwards, that is, when the pluralis maiestatis was becoming pragmaticalized (Svennung, 1958: 8182).

Evidence for the vitality of the nominal strategy in the address system comes from the fact that when Christianity began to spread systematically, there was a process of resemanticization of earlier titles and address forms such as frater 'brother'. Within the Christian religious community, authors however modified frater with adjectives referring to the religious lexicon, such as sanctus 'holy':

(8) Cypr. XII Salutant te fratres tui Calpurnius et Maria et omnes sancti fratres

'Your brothers Calpurnius and Maria and all holy brothers greet you'

Parallel to that, the collective noun fraternitas is widely employed to refer to the whole Christian community in its entirety, and its use reinforces the sense of belonging to a unified group. Adjectives such as omnis 'all' and universa 'all together' exemplify this trend: 


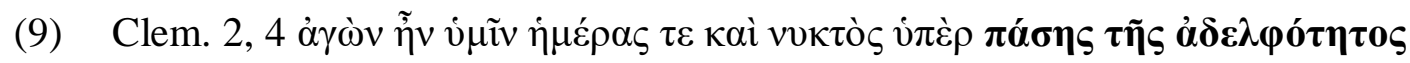

Sollicitudo erat vobis die ac nocte pro omni fraternitate

'Day and night you were very careful of your entire community'

(10) Cypr. ep. XIX Fraternitatem universam meo nomine salutate

'In my name greet the whole community'

Similar adjectives, like christianissimus 'very Christian' and beatissime 'very blessed' also modify other address terms which were already part of the Latin traditional address system, such as princeps or imperator. The following examples, drawn from Ambrosius' Letter XX, show how the selection of religious-connoted modifiers serve to resemanticize an earlier address term:

(11) 1, 1 christianissime principum

'very Christian among the emperors'

(12) XL, 1 Imperator beatissime

'very blessed emperor'

As these examples have shown, nominal forms constitute a majority strategy in the Latin system of address along a long diachronic span: Christian authors rely on the address system which was already used in Early and Classical Latin, partially adapting it with reference to their own religious perspective and modifying earlier lexical items by means of resemanticized adjectives (sanctus, beatus) or new ones (christianus).

A new development emerging in the $3^{\text {rd }}$ century CE is constituted by the pluralis maiestatis, which is likely to have stemmed from the systematic use of the pluralis modestiae in formal contexts. A crucial role was played at this juncture by a specific type of text: imperial rescripts, documents that were issued in response to a specific demand made by its addressee, typically on juridical matters. These legal texts were in many cases prompted by the emperor, who tended to adopt different forms of honorific self-designation, including plural verbal forms such as iudicamus "we judge", permittimus "we permit", and abstract nominals, as in (14) from the Codex Theodosianus (398 CE).

(13) Codex Theodosianus (398 AD) 11, 30, 56 Repugnantes priscorum sententias nostra serenitas 


\section{temperavit}

'Our Serene Highness moderated those who made resistance to the decisions of the ancestors' According to Hofmann (2003: 292), the pluralis maiestatis spreads from the fifth century onwards. Once conventionalized as a pragmatic strategy to express honorific self-evaluation, the pluralis maiestatis triggered the complementary use of 'illogical' second plural reference in place of a second singular reference ${ }^{16}$, which was re-interpreted as a deferent form of address: the pluralis reverentiae. This type of pluralization progressively became the conventional, ritualized strategy to express social distance and as such was codified in the social deixis system (Molinelli, 2015b). Once part of the system, the pluralis reverentiae rapidly spread in all those social environments that were heavily influenced by official registers; Norberg (1999: 27) reports that this kind of plural was even used as a polite form to address colleagues in specific socio-cultural contexts. It occurs in Symmachus (Haverling 1995) ${ }^{17}$, later in Cassiodorus and Gregorius Magnus (Hoffman and Szantyr 1965 II: 2021). This use of the second plural reference pragmatically interpreted as a deferent address form subsequently passed into early Romance varieties. To cite an example, Dante uses the plural voi 'you' to express respect and social distance with interlocutors such as Farinata and Cacciaguida, who, by contrast, addresses Dante with the $t u$ form (Ronconi 1946: 4).

The analysis of nos just outlined above has shown that the use of the pronoun as a cooperativeinclusive plural is the first pragmatic value to emerge. This function relies on modulations of the affective distance, typical of symmetric relations. Therefore, the inclusive plural is a linguistic means that reflects different degrees of intimacy between interlocutors sharing the same power and social status.

\footnotetext{
16 The label of 'illogical' is used by classicists (e.g. Haverling 1995), while recent studies include these plurals in "nonprototypical uses of personal pronouns" (Helmbrecht 2015).

${ }^{17}$ According to Haverling (1995: 337-338), the earliest indisputable examples of vos (instead of $t u$ ) to express deference, respect and, more generally, social distance, first appear in Symmachus (Epist. 1, 3) - and this in spite of diverging authoritative interpretations: "Some recent experts of Symmachus take the plural in this and other passages to be sociative [...] In my view, however, we are actually dealing with examples of an 'illogical use' of the plural".
} 
A crucial development is represented by the emergence of the honorific value, which the speaker could use in order to self-evaluate himself positively: the pluralis maiestatis, a subjectively marked evolution of the sociative-inclusive plural, with which the speaker expresses himself as a collective plurality, self-representing himself as a subject that "counts more". This is a key development in the diachrony of Latin social deixis, since it links older values with further functions related to deference and respect. In other words, speakers using the pluralis maiestatis first marked an idea of social distance and asymmetric relation, which augmented the difference with the interlocutor. Significantly, while the inclusive plural flourished in the republican period, the pluralis maiestatis was initially used in the imperial age, by Roman Christian authority (Pope Clement I, ca. 91-101) and subsequently by emperors, starting from Gordianus III (238-244) (Sasse, 1889: 7, 53, 55). The widespread interpretation according to which the pluralis maiestatis (and therefore the pluralis reverentiae) had a concrete rather than an abstract use is therefore significantly challenged ${ }^{18}$.

A complementary development is the pluralis reverentiae, used as politeness acknowledgement of the positive image of himself asserted by the speaker. This plural shares with the pluralis maiestatis the fact that the interlocutors have asymmetric degrees of power. Politeness and reverential forms rapidly became ritualized and codified within the system: this led to the pragmatic encoding of distance by means of the complementary functional development of vos (cf. Haverling 1995, for an earlier debate). The complementary role of the pluralis reverentiae with respect to the pluralis modestiae is explained by Schmid (1923: 479) in terms of a symmetrical interactional relation featuring a question inflected in the first-person plural that triggers an answer inflected in the secondperson plural. Older examples of this pragmatically driven function are also found in Ancient Greek

\footnotetext{
${ }^{18}$ A long debate links the $p l$. maiestatis to the presence of two emperors in the Roman Empire from the end of the II century BCE onwards (Brown and Gilman 1960: 254 for a summary). As there were two emperors, this would justify the referential plural nos and the association with supreme power and authority. Without going into detail, I would like to recall that the Roman republic had double public office with two consuls, as well. This fact, by itself, does not explain the majestic plural. In order to discuss the connection between the development of the address system and the sociopolitical changes, the deep divergences between the republic and imperial Rome should be taken into account, as well as the role of the Christian hierarchy during the first centuries BCE. This topic merits further investigation.
} 
(see, e.g., Schmid 1923: col. 479) and in typologically distant languages ${ }^{19}$. Uspenskij emphasizes that we are dealing with linguistic processes that are anchored in specific socio-cultural and historical contexts, which, however, are motivated in terms of communicative and cognitive principles that are cross-linguistically valid (2008: 134).

It is important to observe here that the process of pragmaticalization leading to the conventionalization of these address formulae, mirroring the emergence of new social rituals, can be better understood if linked to the socio-historical context of the time. As early as the $3^{\text {rd }}$ century CE the Roman Empire was torn by both internal and external crisis: Rome lost part of its political hegemony and cultural primacy, while neighbouring peoples were pushing from the East. As a result, the balance of power between senate and emperor shifted dramatically towards the latter and his court: as Norberg (1968: 14) writes,

The emperors imposed on society a caste system according to which all were linked to a certain profession and a certain social class. At the same time a new system of honorific titles was instituted. The emperor could be called gloriosissimus, serenissimus, christianissimus, the functionaries were divided into four classes of which the attributes were illustres, spectabiles, clarissimi, and perfectissimi. The emperor was addressed by the words vestra maiestas, vestra gloria, vestra pietas, others were addressed, depending on their rank, vestra excellentia, eminentia, magnificencia, spectabilitas, etc. The titles beatitudo and sanctitas were preserved for ecclesiastical dignitaries.

Summing up, in Late Latin nominal and pronominal strategies attest the shift from address forms based on symmetric relationships to asymmetric ones. Non-prototypical uses of personal pronouns shift from inclusive to exclusive; several bridging contexts attesting pluralization in the first person are difficult to interpret as referential-majestic. From non-prototypical majestic nos a symmetrical exclusive strategy develops: reverential vos, both in the secular and in the Christian domains.

\footnotetext{
${ }^{19}$ Head 1978, Helmbrecht 2003 and 2015 are worthwhile readings, together with the 45A map of the World Atlas of Language Structures "Politeness Distinctions in Pronouns", http://wals.info/feature/45A\#2/25.7/137.0.
} 


\section{The system of address in Italian}

\subsection{Old Italian}

The system of address in 13th and 14th century Italian reflects the development just outlined in Late Latin: it is characterized by a two-term system where $t u$ is the unmarked pronoun of address and $V o i$ is used as a deferent form (Niculescu 1974; Renzi 2002, 2010).

$T u$ is used in communication with deities (e.g. man-God), and in informal relations, irrespective of the social status of the interlocutors, as in (14), where the noble friends, who are the storytellers in Boccaccio's Decameron, address each other with tu:

(14) Pampinea per Dio, guarda ciò che tu dichi (Boccaccio, Decameron, I, Introduction)

'For God's sake, Pampinea, have a care what you say'

$T u$ is also used to show high-affective-distance in symmetrical relations, as between members of the lower and middle classes. In (15), Andreuccio, a man-servant from Perugia, rings the bell of Madonna Fiammetta in Naples, and one of her servants addresses him with $t u$. "Chi picchia là giù?" "Oh!" disse Andreuccio "o non mi conosci tu? Io sono Andreuccio, fratello di madama Fiordaliso." Al quale ella rispose: "Buono uomo, se tu hai troppo bevuto, va' dormi [...]” (Boccaccio, Decameron, II, 5)

، 'Who knocks below there?' 'Oh!' said Andreuccio, 'dost not know me? I am Andreuccio, Madam Fiordaliso's brother.' 'Good man,' she rejoined, 'if thou hast had too much to drink, go, sleep it off'

$T u$ is also used in asymmetrical high-social-distance relations to address lower-status members. In (16), the friar addresses Sir Ciappelletto with a tu verbal form "hai fatto", but is answered with the Voi predicate non dite,

Disse (...) lo frate: Figliuol mio, bene hai fatto, e così si vuol fare per innanzi (...). Disse ser Ciappelletto: -Messer lo frate, non dite così...(Boccaccio, Decameron, I, 1) 
' 'Son,' said the friar, 'thou hast done well, and well for thee, if so thou continue to do.'

'Nay but, master friar,' said Ser Ciappelletto, 'say not so [...]'

However, the deferent address also characterizes asymmetrical relations with low affective distance, as father to son:

A voi ser Guido padre mio sine peccato io Guiduccio vi mando salutem cum desiderio revidendi (1253, Lettera sangimignanese di Guiduccio al padre, Corpus OVI)

'To you sir Guido, my father, without guilt, I Guiduccio send my regards with the desire to see you'

Voi can also be used in symmetrical relations, as in courtly literature where all nobles address each other with Voi:

Ma sopravvenendo messer Gentile, disse alcun de' suoi forestieri: "Messere, bella cosa è questa vostra, ma ella ne par mutola: è ella cosí?” (Boccaccio, Decameron, X, 4)

'Then, Messer Gentile coming up: 'Sir,' quoth one of the guests, 'this treasure of yours is goodly indeed; but she seems to be dumb: is she so?"

Within nominal address terms, the use of titles is widespread to address people with power. Typically, titles appear in an NP with a feminine abstract head, as in (19), where signoria is used together with the deferent second person plural vostra, but with third person singular agreement in the verb potrà. Segundo che la v(ostra) signoria vedere potrà p(e)r publico i(n)strum(en)to (Guido Faba, Parlamenta, Corpus OVI)

'On the basis of what your lordship will see in public documents' Usually these titles refer to a quality, as in Latin (cf. maiestas). Yet, the contexts in which these titles are used are bridging (see fn. 13) since it is often impossible to decide whether they express a virtue attributed to the addressee or the interlocutor him/herself as the embodiment of that virtue. In such contexts, Vostra Signoria is meant literally to refer to a Lord.

On a formal level, such titles often co-occur, as in (19), with second person plural reference in ritualized expressions. In these centuries, it is possible to find oscillations of verbal agreement in 
sentences containing nominal address. Migliorini (1957: 189) notes that in the 13th century the most frequent address sequence is the deferent nominal address (i.e. Vostra Signoria), followed by verbs and pronouns in the second person plural:

\section{[...] p(re)ghiamo la vostra signoria che (con)tra noi no(n) aoperiate ve(n)decta ma humilità}

(Trattati di Albertano volg., a. 1287-88 (pis.) Liber cons., cap. 50 5018.59)

'[...] we pray Your Lordship that you not exact any revenge on us

but humility'

In the 14th century, by contrast, the more common address sequence employs reference to the abstract formula and uses third person singular feminine pronouns and third person verb agreement accordingly (as Vostra Signoria potrà in 19). The verbal agreement is not with Voi, although it appears in the preceding and following sentences, but with the nominal address.

In sum, in Old Italian Voi and concomitant forms are used as deferential address forms in asymmetrical exchanges with high affective distance by lower-status members to address higherstatus interlocutors; nominal address terms can also be used. Persons equal in power, depending on their status, can alternatively use Voi. Tu is typical of intimate relations, while Voi is used in asymmetrical but intimate relations (e.g. son to father).

In such a system speakers position themselves according to social status, class, and, more generally, power relations: therefore the use of $t u$ is typical in common people, while Voi is more common among nobles.

\section{$4.216^{\text {th }}$ century}

In the 16th century, the study of any linguistic phenomenon must take into account the debate on the Questione della lingua. ${ }^{20}$ Therefore, we have decided to analyze the system of address in a Tuscan sample. Pietro Aretino's comedy La Cortigiana is characterized by the use of $t u$ and Voi as pronouns of address. Power equals use $t u$ with low affective distance, especially if they are members of the

\footnotetext{
${ }^{20}$ The comedy La Cortigiana dates from 1525. At about the same time, Le prose della Volgar Lingua by Bembo were also published. These publications played an important role in the discussion of the Italian Questione della lingua (the debate concerning the preferred form of the national language).
} 
lower class who are well acquainted with each other, as in (21), where Cappa and Rosso, two servants working together, address each other with $t u$.

CAPPA Tu sei molto alegro, Rosso; tu vai ridendo da te stesso. 'You are very happy, Rosso. Why are you smiling to yourself?'

ROSSO Io mi rido d'una giuntaria ch'è stata fatta [...], e te la conterò piú per agio. 'I am smiling because of a scam I carried out, and I'll tell you about it calmly' (Aretino, $\mathrm{La}$ Cortigiana, I, 20)

$T u$ is also used in asymmetrical interactions by people with higher status to address those of lower status. In (22), a sacristan addresses a fisherman with $t u$. SAGRESTANO Tu non odi, an? 'Can't you hear? Can you?'

PESCATORE Eccomi servitore de la Signoria Vostra, infatti. 'Here I am servant of Your Lordship' (Aretino, La Cortigiana, I, 19)

However, compared with the situation in Old Italian, the domain of use of Voi is expanding as the unmarked deferent form of address signaling respect in both asymmetrical (22) and symmetrical interactions, as in (23), where an old domestic addresses a baker's wife with Voi.

(23) E voi, moglie di messer Ercolano, entrate con Aloigia. (Aretino, La Cortigiana, V, 22)

'You, wife of sir Ercolano, enter with Aloigia'

Nominal terms of address can co-occur with second person plural pronouns ( $V o i)$ as well as with third person singular pronouns (Lei, Ella), and verbal forms correspond. This is particularly evident in letters, where writers show a certain degree of variation depending on the addressee and on the type of relationship.

Examples (24) and (25) drawn from letters by Torquato Tasso are cases in point. In (24), addressed to an intimate family friend, the author switches from the usual second person plural forms of address (Voi and avete) to Vostra Signoria and third person singular agreement, when asking his friend for a favour. In (25) Tasso writes to Doctor Verini, who had commissioned a sonnet from him; throughout the text the poet uses third person singular address. 
(24) Del mio venire a Ferrara non sono tanto risoluto quanto vorrei, perché voi non avete voluto ch'io n'abbia maggior certezza. De' cinque ducati ho bisogno; però scrivo di nuovo a fra Iacomo, e prego Vostra Signoria che gli dia la lettera. (Tasso, A Luca Scalabrino, G885)

'I am not so sure of my coming to Ferrara as I would like to be, because you did not want me to have more certainty [about it]. I need five ducats; but I am writing again to Friar Giacomo, and I pray Your Lordship to give him the letter'

(25) Mando a Vostra Signoria il sonetto sovra il nome di Pandolfina, ch'ella m'ha chiesto. [...] se le piacerà di rimandarmene copia, risponderò volentieri. (Tasso, Al dottor Verini, G186) 'I send to Your Lordship the sonnet on Pandolfina that you have asked of me. [...]. If you will be pleased to send me back a copy, I will answer gladly'

It is possible to hypothesize that speakers used the third person address, usually co-occurring with titles, in asymmetrical interactions with high affective distance, as is presumably the case in (25).

Several scholars ${ }^{21}$ have stressed that the spread of this use can be traced back to the influence of Spanish culture. At the time, Spanish dominion characterized some territories in the South (Naples, Kingdom of the Two Sicilies), and part of the North (Lombardy). Migliorini (1957) notes that in this century, the use of titles increases dramatically. Their semantic field expanded, and such forms as Vostra Reverenza "Your Reverence", Vostra Padronità "Your Mastership", Vostra Magnanimità "Your Magnanimity" are attested. Vostra Signoria "Your Lordship" is the most frequent title referring to people of quality or power (regardless of their social status).

\subsection{8th century}

In the 18th century, here analysed through Goldoni's comedies La famiglia dell'antiquario (henceforth, fam.) and L'uomo di mondo (henceforth, uomo), the system of address developed further along the same direction. Interlocutors used a tripartite system where $t u$ was selected in asymmetrical

\footnotetext{
${ }^{21}$ See Migliorini (1957) for the discussion.
} 
interactions characterized by both high and low affective distances. For instance, a master addresses his servant with $t u$ in (26).

BRIGHELLA La me perdona; ma buttar via tanti bezzi in ste cosse... 'Please forgive me, but to throw away so much money on these things...'

ANSELMO Buttar via? Buttar via? Ignorantaccio! Senti se vuoi avere la mia protezione, non mì parlar mai contro il buon gusto delle antichità. 'Throw away? Throw away? Idiot! Listen, if you want to stay in my service, do not speak against the good taste of antiquities' (Goldoni, fam., I, 1)

In our plays, characters also use $t u$ in low-affective-distance interactions to express strong emotions, such as anger or affection. In (27) Pantalone, a middle-class merchant, is asking his daughter Doralice, married to a nobleman, to get on well with her mother-in-law. The interaction begins with Voi, but in the course of the conversation, when the father shows affection to her, he switches to $t u-$ and, simultaneously, to Venetian dialect. DORALICE Signor padre, vi ringrazio dell'amorosa correzione che mì fate. 'Sir father, I thank you for the kind correction that you are offering me' PANTALONE Vostra madonna sarà in tutte le furie, e con rason. [...] Via, cara fia, dàme un poco de consolazion. No gh'ho altri a sto mondo che ti. Dopo la mia morte, ti sarà parona de tutto. 'Your mother-in-law will have flown off the handle and she is right. [ ...] Come on, dear daughter, give me some consolation. I do not have anybody else in the world, excepting only thee. After my death thou wilt own everything'. (Goldoni, fam., I, 20)

As for third person address, its domain has broadened. In many contexts speakers use the third person singular feminine pronoun of address alone, without co-occurring titles, most frequently in the forms Ella (subject) or Lei (object or oblique cases). This choice generally is due to formality and deference. Sometimes, servants who are not well acquainted with their masters use these forms, as in (26), where Brighella addresses his master with a third person pronoun. However, more frequently, middle-class people use the third person feminine when addressing higher classes, as in (28), where Pantalone, a 
middle-class merchant, addresses his daughter's father-in-law, a nobleman, with ella (a feminine pronoun), and uses masculine agreement (virtuoso). Interestingly, the man in turn addresses him with a second plural form.

ANSELMO Ridete, perché non ve n'intendete. 'You laugh because you do not know these things'

PANTALONE Benissimo, mì son ignorante, ella xé virtuoso. 'Well then. I am ignorant and you are clever.' (Goldoni, fam. I, 18)

Speakers also use third person forms to address strangers with high (or perceived high) social status, as in (30), where Arlecchino, disguised as a merchant of antiquities, addresses Pantalone with third person forms.

PANTALONE Galantomo, chi seu? Chi domandéu? 'Gentlemen, who are you? Who are you looking for?'

ARLECCHINO Innanz che mì responda, l'am favorissa de dirme chi l'è vussiorìa. 'Before I answer you, please tell me who Your Lordship is'

PANTALONE Son un amigo del sior Conte Anselmo. 'I am a friend of Count Anselmo'

ARLECCHINO Se dilettela de antichità? 'Are you interested in antiquities?' (Goldoni fam.,

II, 12)

The domains of the second plural forms have also broadened. Voi is the unmarked form for showing respect in virtually all types of interactions. It can be used by lower classes to address higher classes (especially if they are well acquainted with them), by upper or middle classes when addressing lower classes (as in 28), among equals in higher or lower classes, as in (30) and (31) respectively.

ISABELLA Cavaliere, siete venuto a tempo. Ho bisogno di voi. 'Chavalier, you arrive at the right moment. I need you."

CAVALIERE Comandate, signora. Disponete di me. "Order, Milady. At your disposal' (Goldoni, fam., I, 14) 
MOMOLO Stè anca fina doman, se volè. 'You can stay up until tomorrow if you want' TRUFFALDINO Sorella, ve lasso in compagnia de sto sior. 'Sister, I leave you in the company of this Sir' (Goldoni, uomo, I, 15)

However, it should be stressed that characters used a type of address not predetermined by their social class, but to position themselves and their interlocutors in the course of interactions, being constantly negotiated. This suggests that considerations relating to social status were no longer paramount in the 18 th century.

Example (32) illustrates this point. All characters are lower- or middle-class people at Brighella's inn. Brighella addresses Silvio, one of his lodgers, with a third person feminine reference, while Silvio, according to his higher status, replies with the second person plural pronoun. At this point Silvio turns to the Doctor, another of his lodgers. The two, who have just met, begin a conversation with a third person form of address. At one point the Doctor invites his interlocutor to come and visit him. This invitation has the effect of reducing affective distance, thus determining a shift to the less formal, but respectful, Voi. The change of address form in its turn has an effect on the social positioning of the interlocutors.

(32) BRIGHELLA Eccola là, quello l'è el sior Dottor che la cerca. (a Silvio) 'There you go, the man over there is sir Doctor who is looking for you'.

[...] SILVIO Favorisca vedere se questa lettera viene a lei. 'Please, consider if this letter is for you'

DOTTORE [...] Permetta ch'io veda. Ella dunque è il signor Silvio Aretusi romano? 'Can I see it? You are then Sir Silvio Aretusi, from Rome?'

SILVIO Per obbedirla 'At your service'.

[...] DOTTORE L'amico mi raccomanda lor signori, ed io li prego venir in casa mia, ove staranno un po' meglio forse di quel che stiano nella locanda. 'My friend has recommended your Lordships, and I pray you to come to my house where you will maybe be more comfortable than in the inn' 
SILVIO Signore, io non intendo d'incomodarvi.'Sir, I do not want to inconvenience you'

(Goldoni, uomo, III, 8)

Nominal terms of address continued to be very common in the 18th-century. As seen in (29), the frequency and ritualization of titles in the preceding centuries had created frozen variants of the more frequent form Vostra Signoria as Vussioria, Vossustrissima, or Lustrissima (derived from Vostra signoria illustrissima 'Your illustrious Lordship').

In sum in the 18th-century, deferential address towards upper social levels had already switched from the previous Voi, which had become too common, to the more refined Vostra Signoria, to third person singular pronouns, and related forms. Voi has instead become the unmarked form of address used in both symmetrical and asymmetrical interaction to show respect, irrespective of social status. Conversely, intimate relations are given more prominence, and $t u$ is used to address members of higher classes in moments of anger or special empathy.

\subsection{0th-century}

During the 20th century, the system of address is characterized by a rapid evolution, deeply triggered and influenced by the economic, political, social, and cultural transformations that characterize the historical period.

$T u$ is used in both asymmetrical and symmetrical interactions. Asymmetric $t u$ expresses social distance from higher- to lower-status people at the beginning of the century, but this use is absent at the end of the century. Symmetrical $t u$ is used among family members and more generally to indicate low affective distance. This holds true for texts written throughout the century.

The two uses are exemplified in (33) and (34) respectively. In (33) Tommy, the son of a wealthy nobleman, addresses his servant Lucia with $t u$.

TOMMY Gaspare. Dov'è Gaspare? 'Gaspar! Where is Gaspar?'

LUCIA $\grave{E}$ in cortile per il carico. 'He is in the yard for the load' 
TOMMY È mezz'ora che lo chiamo. Digli che salga a finire di vestirmi. 'I have been calling him for half an hour. Tell him to come up and help me get dressed' (Giacosa, Come le foglie, I, 1)

Similarly, in (34) a husband addresses his wife with $t u$, and in the letter in (35) a soldier addresses his aunt with $t u$.

GIOVANNI Ieri mi avevi domandato ottanta lire per comprare dei colori. Ti ho supplicato di non far spese, ti ho detto che ho i danari contati! 'Yesterday you asked me for eighty lire to buy some paint. I begged you not to buy anything, as I do not have much money left' (Giacosa, Come le foglie, I, 7)

Cara zia, ricevo ora la tua lettera e come pure ricevetti la cartolina nel quale sento ciò che mi dici e ne sono assai dispiacente. 'Dear aunt, I have just now received your letter as I received your postcard where I read what you tell me. I am really sorry about that' (Palmieri, Lodi 14/1/1917)

In this century Lei spreads as the unmarked deferent address form at the expense of Voi. At the beginning of the 20th century, unmarried men and women use Voi to express respect in all types of interactions, as both letters and comedies testify: (36) and (37) are cases of symmetrical Voi.

Da molto tempo sapevo di esservi antipatico: forse prima ancora che lo sapeste Voi (Gozzano, Lettere d'amore, S. Giuliano d'Albaro, 10 giugno 1907) 'I have known for a long time that you did not like me, maybe even before you knew it' GIULIA Ho una piccola memoria per voi. Aspettate. [...]'I have a present for you. Wait!'

HELMER Il vostro ritratto! Com'è bello. [...] 'Your portrait. How beautiful!' (Giacosa, Come le foglie, III, 7)

The same uses are not attested in comedies at the end of the century, where Voi is only used by older characters of higher social ranks or by characters who use a Southern variety; see (38) and (39) respectively. In (38), Countess De Santis, an elderly lodger, addresses Gennaro, the owner, with Voi, 
having received a third person address. In (39), the same Gennaro, who is from Naples, uses Voi when he resorts to his Southern variety.

GENNARO Contessa De Santis, tra un diritto e un rovescio, per caso ricorda anche che mi deve quattro mesi di arretrati? 'Countess De Santis, between a plain and a purl, do you by chance remember that you also owe me four months' arrears?'

CONTESSA E dagli! Sempre la solita storia! Soldi, soldi...ma non sapete pensare ad altro, voi? 'Come on! It's always the same story! Money, money... can't you think of anything else?' (De Piramo, Pensione Marechiaro, I, 7)

GENNARO Era pure nervosa come voi, signò 'She was also as nervous as you, madam' (De Piramo, Pensione Marechiaro, I, 2)

As for third person address, its use as the unmarked deference form is spreading into domains, which were characterized by $V o i$ in preceding centuries. The different variants of third singular feminine pronouns (Ella and Lei), which were widespread during the 18th century, are less frequent, and the form Lei becomes the unmarked pronoun used as subject.

Third person feminine address is used reciprocally to show deference in asymmetrical interactions between members of different social status, as in (40), where a seamstress uses the third person to address her client, a noblewoman, and in the letter in (41), where a soldier addresses an officer.

(39) LABLANCHE Se la signora me lo avesse detto due o tre giorni fa.... 'If madame had told me two or three days ago ...'

GIULIA Ha ragione.... m'è passato di mente. 'You are right. ... I forgot' (Giacosa, Come le foglie, 1900, I, 5)

(40) Gentilissimo Sig. Della Rovere, non so come ringraziarla del gentile interessamento. 'Dear Mr. Della Rovere, I don't know how to thank you for the kind interest' (Cuccioli, war zone, 25/3/1917)

However, strangers also use the same form in symmetrical interactions, as in (42). CONTESSA Era lei l'uomo nudo? 'Was it you who was the naked man?' 
PROFESSORE Come può constatare...con chi ho il piacere di parlare? 'As you can see ... with whom do I have the pleasure of speaking?'

CONTESSA Sono la Contessa Marisa De Santis ‘I am Countess Marisa De Santis’ (De Piramo, Pensione Marechiaro I, 7)

As for titles, it is interesting to note that the more common title that characterizes the 18th century, Vostra Signoria, is attested only in a few letters (43, in the short form S:V:), probably a more conservative genre in this regard. In comedies, however, Signore and Signora become the unmarked deferent terms of address (see ex. 40).

$$
\text { Illmo S. Sindaco Di Persiceto[...] Il sottoscritto [...] rivolge alla S:V: Ill'mo preghiera }
$$

[...] 'Dear Mr. Mayor of Persiceto, the undersigned pray your Lordship [...]' (Muzzi, war zone, 13/6/1916)

Speakers use Lei in both symmetrical and asymmetrical interactions to show deference and respect, and use $T u$ in symmetrical interactions to express low affective distance. Voi remains the unmarked deferent pronoun in some regional varieties, especially in the South.

As for third person address, it is relevant to note that during the 20th century people had different opinions on its use. Some considered it the proper form of address among civil, well-educated people, who are not exceptionally servile or given to flattery. Some, on the other hand, considered it to be the effect of the negative influence of the Spanish language. It is worth mentioning that especially during the Fascist regime, authoritarian measures were taken to stamp out Lei, but they had no permanent effect.

On January 15, 1938, Bruno Cicognani wrote an article in the Corriere della Sera denouncing what he called "a grammatical and syntactic aberration" (i.e. Lei), which he considered to be the result of exceedingly courtly Spanish manners during the 16th century - of affectation of feelings, ideas, and words. He therefore suggested returning to the Roman system of address and to Voi as a sign of respect and recognition of hierarchy. Many Fascist newspapers took up the arguments orchestrated 
by Cicognani, and soon circulars forbade the use of third person address, first among members of the party, then in the Fascist Youth, and gradually among State employees, the military, and educational institutions. The ban had been widely defied anyway - militantly by some, but also by the majority because it is not possible to alter a centuries-old practice ${ }^{22}$ by simple decree.

\subsection{Present-Day Italian}

In Present-Day Italian, the system of address comprises nominal forms, including a wide range of names (e.g., proper names), kinship terms, titles (signore 'Sir'), military ranks (Sergente 'sergeant') and work-related terms (Professore 'professor') ${ }^{23}$. The nominal system has progressively reduced over time ${ }^{24}$.

In standard Italian, the unmarked deferential form implies the use of the anaphoric third person singular feminine pronoun (Lei), and related forms, to refer to the interlocutor (be it feminine or masculine). Other deferential forms include the use of first person plural (noi) in place of first person singular pronoun (io) to refer to the speaker, and of third person plural (Loro) instead of second person plural pronoun (voi) to refer to more than one interlocutor.

In areas where speakers still use Voi alongside Lei, Voi is perceived as the less deferential of the two. In other areas in Central (Marche, Umbria, Abruzzo) and Southern Italy (especially Campania, Calabria, and Salento), local dialects do not have a deferential form, which implies a more marginal use of Lei.

Therefore, speakers with intimate and symmetrical relations (two friends, colleagues) will use $t u$, while speakers with symmetrical but distant relations will use either $t u$ (e.g. a teenager asking directions in the street from another teenager) or Lei (e.g. older speakers in the streets asking directions).

In asymmetrical relations, forms are typically non-reciprocal ( $t u$ will be used by higher status members, who in turn will receive Lei). However, especially when affective distance is also high,

\footnotetext{
${ }^{22}$ For an analysis of the situation during the Fascist regime, see Raffaelli (1993).

${ }^{23}$ See several chapters focusing on different languages in Taavitsainen and Jucker (2003).

${ }^{24}$ Molinelli 2010 and 2015a provide further examples and discussion.
} 
reciprocal Lei forms may be used. Interestingly, in varieties of Italian where Voi is still used, coexisting with $L e i$, it tends to characterize non-reciprocal relations and to be an intermediate form between $L e i$ and $t u$ in terms of affective distance.

In Present-Day Italian, which in recent years has undergone a striking loss of formality in relationships between people, the use of $t u$ has been generalized among speakers in asymmetrical relations, such as doctor-patient. The same is true in cases of symmetrical but affectively distant relationships, such as encounters among adults meeting for the first time.

\section{Concluding remarks}

This chapter has outlined the diachronic development of the system of address from Classical Latin to 20th century Italian, attempting to associate what we can see in written texts to the speakers' choices in interactions. Now, let us consider the evolution of the address system in the long diachrony from a linguistic and sociocultural perspective.

In Early Latin the surviving texts show that the nominal strategy is the one primarily used; then in Classical Latin sociative/inclusive values of the plural nos emerge, while in the Imperial period it is possible to outline the development of the pluralis maiestatis and reverentiae. In Latin, therefore, social positioning in the address system is dependent on a lexical strategy as deference mostly relies on the use of titles. The morphological strategy of pluralization emerges from first person plural reference with inclusive meaning. The following schema can summarize the subsequent steps of such strategy:

Nos $=$ ego $\quad$ inclusive $\rightarrow$ majestic

$V o s=t u \quad$ inclusive $\rightarrow$ deference

Only later does this deference value develop and become the first, basic mechanism for deference in Old Italian, and more generally in Romance languages. However, between the 13th and 16th centuries, honorifics still have a relevant role in the Italian system of address and trigger anaphoric abstract reference to a third person (Vostra Signoria and third person related forms). These alternatives are then morphologised as third singular pronouns (Ella and Lei). For some centuries, 
Italian has a three-term system of address where two deferent forms coexist (Voi and Ella/Lei). The two forms imply the use of two different morphological mechanisms to express deference (Serianni 2006: 224):

- 2 p-as-2s-deferent (Voi): speakers refer to an individual as if on the basis of his/her merits, prestige, or authority he/she "had the worth of two";

- 3s-as-2s-deferent (Lei): speakers refer abstractly to the "lordship" or "highness" of the other, as if it were too daring to address him/her directly.

In the 20th century, speakers tend to reduce the system of address again: in standard Italian the unmarked deferent form is Lei, while Voi survives only in some regions both in regional Italian and in local dialects.

In order to understand the linguistic development of the address system over the centuries, the role of socio-cultural factors motivating pragmatic choices is substantial.

In Latin, changes in address choice are to be connected with the contemporary socio-political and cultural situation: the pluralis maiestatis, entailing a positive self-evaluation, emerges in the Imperial age, where the political system is basically structured around the prominent figure of the emperor and, from the end of the $1^{\text {st }}$ century $\mathrm{CE}$, of the high Christian hierarchy, and triggers later developments, such as the complementary strategy of the pluralis reverentiae and the productive system of honorific titles, which is instituted after the $3^{\text {rd }}$ century, when a caste system where all are linked to a certain profession and a certain social class is established, along with the emergence of religious hierarchies (Molinelli 2015b).

Instead, the parameters of social distance and affective distance are relevant throughout the centuries of the history of Italian considered, but to different degrees as parameters connected with social distance seem more relevant during the 13th century, while those relating to affective distance are paramount from the 18th century.

When Voi extends its domains of use, it becomes so commonplace that it ceases to accomplish a deferential function; it marks affective distance (i.e. respect), but no longer social distance, which 
becomes served by Lei. In turn, in the pragmatic development of Lei several factors play a role. One of these is contact with Spanish culture, where codes of behavior in society associated with ceremony and with the use of titles, are paramount.

Summing up, the use of nominal address forms is particularly frequent in two time periods, Late Latin from the 3rd century CE on, and 18th-century Italian. As said for the development of the Italian address system, once a title is used to address somebody, the successive references are anaphoric forms which lead to the development of a third-person deferent form.

Therefore, different factors are at play in triggering different changes in the internal configuration of address choice domains in diachrony. Whereas the emergence of reverential forms in the history of Latin is mainly due to socio-cultural factors - the emergence of a more rigid social stratification and of religious hierarchies -, the change leading from the use of Voi to the predominant employment of Lei in the history of Italian is due to both social reasons (contact with Spanish) and linguistic factors, since the massive use of honorifics triggered anaphoric abstract reference to a third person, then morphologised as third singular pronouns (Lei).

The creation of the $t u /$ Vos opposition, starting from a ego/Nos alternation, recruits linguistic forms, which already exist as deictic elements and assume a new metaphorical and pragmatic value. The formation of the Italian Lei system is quite different in nature: the "other" becomes a third person and along some centuries the choice between Lei and Voi underlies social rules (as is for instance the case in the 18th century). In Italian the situation is far from been resolved, though today in the standard variety Voi is no longer in use.

The diachronic process we have described could be better characterized in terms of a series of cyclical developments whereby the nominal strategy continued across the history of Latin and Italian. This strategy is initially highly productive due to the lack of an alternative politeness device in the grammatical system - for instance, the lack of pronouns of address in Early and Classical Latin. When pluralization finally emerges in the 3rd century, names of address are re-functionalized as honorific titles. The established use of the plural form also for the second person as a means to express 
deference constitutes the most important innovation in Late Latin - and as such it continued in Romance languages (see Niculescu, 1974: 12, Watts et al., 1992: 92-93, Janner et al., 2014). The use of the reverential second plural develops as a deviation from the unmarked form that progressively becomes part of the system.

Similar considerations hold true for the development of the Italian address system when pluralization is substituted by third-person reference as deferent. The contact with Spanish has again a role in the return of the nominal strategy of address which paves the way for the upsurge of third-personreference (Sp. Usted, plural Ustedes, < Vuestra merced). However, the "social trend of ceremony" extends in Italy well beyond the Spanish cultural model, with independent development of the system of address, where the third person reference pronoun becomes the unmarked deferent form. In Labovian terms, the change is from above, reaching from higher registers to lower ones (different regional varieties and local dialects). Resistance exists up to the first half of the 20th century, as a rejection of the influence of foreign models, but by the end of the 20th century the cycle is complete.

\section{References}

Andersen, Gisle, and Karin Aijmer. 2011. Pragmatics of Society. Berlin: Walter De Gruyter.

Brown, Penelope, and Stephen C. Levinson. 1987. Politeness: Some Universals in Language Usage. Cambridge: Cambridge University Press.

Brown, Roger, and Albert Gilman. 1960. "The Pronouns of Power and Solidarity". In Style in language, Thomas Albert Sebeok (ed), 253-276. Cambridge: MIT.

Culpeper, Jonathan, and Merja Kytö. 2000. "Data in Historical Pragmatics: Spoken Interaction (Re)cast as writing”. Journal of Historical Pragmatics 1:2: 175-199.

Cuzzolin, Pierluigi, and Gerd Haverling. 2009. "Syntax, Sociolinguistics, and Literary Genres”. In New Perspectives on Historical Latin Syntax. Vol. 1. Syntax of the Sentence, Philip Baldi, and Pierluigi Cuzzolin (eds), 19-64. Berlin: Mouton de Gruyter.

Dickey, Eleanor. 2002. Latin Forms of Address: From Plautus to Apuleius. Oxford: Oxford 
University Press.

Diewald, Gabriele. 2002. “A Model for Relevant Types of Contexts in Grammaticalization”. In New Reflections on Grammaticalization, Vol. 49, Ilse Wischer, and Gabriele Diewald (eds), 103120. Amsterdam: Benjamins.

Ferri, Rolando. 2008. "Politeness in Latin Comedy. Some Preliminary Thoughts". Materiali $e$ discussioni per l'analisi dei testi classici 61: 15-28.

Fridh, Åke J. 1956. Terminologie et formule dans le Variae de Cassiodore. Études sur le développement du style administratif aux derniers siècles de l'antiquité. Stockholm: Almqvist and Wiksell.

Ghezzi, Chiara. 2015. "Thanking Formulae. The Role of Language Contact in the Diachrony of Italian”. In Contatto interlinguistico fra presente e passato, ed. by Carlo Consani, 315-343. Milano: LED.

Haverling, Gerd. 1995. "Illogical vos in Late Latin". In Latin vulgaire - latin tardif IV: Actes du $4 e$ colloque international sur le latin vulgaire et tardif. (Caen, 2-5 septembre 1994), ed. by Louis Callebat, 337-353. Hildesheim: Olms-Weidmann.

Head, Brian F. 1978. "Respect Degrees in Pronominal Reference". In Universals of Human Language. Vol. 3. Word Structure, ed. by Joseph H. Greenberg (ed), 151-211. Stanford: Stanford University Press.

Heine, Bernd. 2002. "On the Role of Context in Grammaticalization”. New Reflections on Grammaticalization, ed. by Ilse Wischer and Gabriele Diewald, 83-101. Amsterdam: Benjamins.

Helmbrecht, Johannes. 2003. "Politeness Distinctions in Second Person Pronouns". In Deictic Conceptualization of Space, Time and Person, ed. by Friedrich Lenz, 185-203. Amsterdam: Benjamins.

Helmbrecht, Johannes. 2015. “A Typology of Non-prototypical Uses of Personal Pronouns: Synchrony and Diachrony". Journal of Pragmatics, 88: 176-189. 
Hofmann, Johann B. 2003. La lingua d'uso latina (It. trans. ed. by Licinia Ricottilli). Bologna: Pàtron. Hofmann, Johann B., and Anton Szantyr. 1965. Lateinische Grammatik. II Band. Syntax und Stilistik. München: Beck.

Janner, Maria C., Mario A. Della Costanza, and Paul Sutermeister (eds). 2014. Noi-Nous-Nosotros. Studi romanzi - Études romanes - Estudios románicos. Bern: Peter Lang.

Lilja, Saara. 1971. “The Singular Use of nos in Pliny’s Letters”. Eranos 69: 89-103.

Malsch, Derry L. 1987. "The Grammaticalization of Social Relationship: the Origin of Number to Encode Deference". In Papers from the 7th International Conference on Historical Linguistics, ed. by Anna Giacalone Ramat, Onofrio Carruba and Giuliano Bernini (eds). 40718. Amsterdam: Benjamins.

Migliorini, Bruno. 1957. "Primordi del lei”. In Saggi linguistici, 187-196. Firenze: Le Monnier.

Molinelli, Piera. 2002. "Lei non sa chi sono io!: potere, solidarietà, rispetto e distanza nella comunicazione”. Linguistica e filologia 14: 283-302. (http://hdl.handle.net/10446/275).

Molinelli, Piera. 2010. "Pronomi allocutivi”. In Enciclopedia dell'italiano, ed. by Raffaele Simone, Gaetano Berruto, and Paolo D’Achille (eds), 47-49. Roma: Istituto dell'enciclopedia italiana Treccani. http://www.treccani.it/enciclopedia/pronomi-allocutivi_(Enciclopediadell'Italiano)/.

Molinelli, Piera. 2015a. "Polite Forms and Sociolinguistic Dynamics in Contacts between Varieties of Italian”. In Contatto interlinguistico fra presente e passato, ed. by Carlo Consani, 283-313. Milano: $\quad$ LED. http://www.ledonline.it/Il-Segno-le-Lettere/allegati/728-ContattoInterlinguistico-Molinelli.pdf

Molinelli, Piera. 2015b. "Plural Pronouns and Social Deixis in Latin: a Pragmatic Development". Studi e Saggi Linguistici LIII (2), Special Issue Ancient Languages between Variation and Norm, ed. by Giovanna Marotta, and Francesco Rovai, 65-88.

Niculescu, Alexandru. 1974. Strutture allocutive pronominali reverenziali in italiano. Firenze: Olschki. 
Norberg, Dag. 1999. Manuale di latino medievale. Cava de’ Tirreni: Avagliano Editore.

Pieri, Maria Pace. 1967. "Singolare e plurale di prima persona nell'epistolario di Cicerone". Studi italiani di filologia classica 39: 199-223.

Raffaelli, Sergio. 1993. "Un lei politico: cronaca del bando fascista (gennaio-aprile 1938)”. In Omaggio a Gianfranco Folena, III: 2061-2073. Padova: Editoriale Programma.

Renzi, Lorenzo. 1993. "La deissi personale e il suo uso sociale”. Studi di Grammatica Italiana XV: 347-390.

Renzi, Lorenzo. 2002. "Tu e voi in italiano antico: da Dante, Paradiso (XV e XVI) al corpus elettronico TLIO”. In Roma et Romania. Festschrift für Gerhard Ernst zum 65. Geburtstag, edited by Sabine Heinemann, Gerald Bernhard, and Dieter Kattenbusch, 269-285. Tuebingen: Niemeyer.

Renzi, Lorenzo. 2010. “Deissi sociale”. In Grammatica dell'italiano antico, ed. by Giampaolo Salvi, and Lorenzo Renzi, 1289-1304. Bologna: Il Mulino.

Ronconi, Alessandro. 1946. Il verbo latino. Principi di sintassi storica. Bologna: Zanichelli.

Sasse, Josephus. 1889. De numero plurali qui vocatur maiestatis. Lepzig: Hoffmann.

Schmid, Wilhelm. 1923. "Pluralis Maiestatis [Majestic Plural]." Philologische Wochenschrift 43: 478-480.

Serianni, Luca. 2006. Prima lezione di grammatica. Roma: Laterza.

Svennung, Josef G.A. 1958. Anredeformen. Vergleichende Forschungen zur indirekten Anrede in der dritten Person und zum Nominativ für den Vokativ. Uppsala: Almqvist and Wiksell.

Taavitsainen, Irma, and Andreas H. Jucker (eds). 2003. Diachronic Perspectives on Address Term Systems. Amsterdam: Benjamins.

Unceta Gómez, Luis. 2014. "La politesse linguistique en latin: Bilan d'une étude en cours". In Dictionnaire Historique et Encyclopédie Linguistique du Latin, Paris-Sorbonne (http://www.dhell.paris-

sorbonne.fr/encyclopedie_linguistique:notions_linguistiques:syntaxe:formules_de_politesse, 
last retrieved, November 11th 2016).

Unceta Gómez, Luis. 2017. "Estrategias de cortesía lingüística en Querolus”. Latomus 75 (1): 140161.

Uspenskij, Boris A. 2008. "Deissi e comunicazione. La realtà virtuale del linguaggio". In Deissi, riferimento metafora. Questione classiche di linguistica e filosofia del linguaggio, ed. by Artemij Keidan, and Luca Alfieri, 107-163. Firenze: Firenze University Press.

Watts, Richard J., Sachiko Ide, and Konrad Ehlich (eds). 1992. Politeness in Language: Studies in Its History, Theory and Practice. Berlin: Mouton de Gruyter. 